\title{
ANALISIS RESIKO PRODUKSI DAN PENDAPATAN PADA USAHA BUDI DAYA TAMBAK UDANG WINDU DI KABUPATEN KOTABARU, PROVINSI KALIMANTAN SELATAN
}

\author{
Risk Analysis of Production and Revenue on Black Tiger Shrimp \\ Farming in Kotabaru District, South Kalimantan Province
}

\author{
*Andi Indra Jaya Asaad, Ruzkiah Asaf, Admi Athirah, dan Erna Ratnawati \\ Balai Riset Perikanan Budi daya Air Payau dan Penyuluhan Perikanan \\ Jalan Makmur Daeng Sitakka No. 129 Maros 90512, Sulawesi Selatan, Indonesia \\ Diterima tanggal: 5 April 2018 Diterima setelah perbaikan: 20 Juni 2019 \\ Disetujui terbit: 10 Desmber 2019
}

\begin{abstract}
ABSTRAK
Komoditas udang Windu di Kabupaten Kotabaru hanya sebagai komoditas primer sehingga nilai tambah yang dimiliki belum dapat dimanfaatkan untuk kesejahteraan masyarakat. Tujuan dari penelitian ini adalah: (1) untuk mengetahui resiko produksi; (2) untuk mengetahui analisis pendapatan usaha petambak budi daya udang windu, dan; (3) untuk mengetahui resiko pendapatan. Penelitian ini dilaksanakan di Kabupaten Kotabaru, Provinsi Kalimantan selatan. Jumlah responden sebanyak 32 orang secara acak. Analisis Data yang digunakan dalam penelitian ini dengan menggunakan analisis kualitatif dan analisis kuantitatif. Hasil penelitian menunjukkan bahwa keuntungan budi daya udang yang diperoleh setiap musim tanam sebesar Rp.11.031.970/Ha/musim tanam, dengan pay back periode sebesar 7,24. Analisis resiko produksi menunjukkan bahwa koefisien variansi produksi sebesar 0,444 dengan batas bawah sebesar $32.225 \mathrm{Kg}$. Sedangkan analisis resiko pendapatan menunjukkan koefisien variansi sebesar 0,427 dengan batas bawah sebesar 2.868.491/Ha/musim tanam. Dari hasil tersebut menjelaskan bahwa petambak udang tidak mengalami resiko terhadap produksi dikarenakan kecilnya resiko produksi dan tingginya harga udang windu.
\end{abstract}

Kata kunci: budi daya udang windu; resiko produksi; resiko pendapatan; pendapatan usaha budi daya

\begin{abstract}
Black tiger shrimp commodity in Kotabaru District is a primary commodity which added value has not been optimized for community welfare. The research aims to (1) identify the risks of the production, (2) analyze the revenue of tiger shrimp farmers and (3) identify the income risk. This research was conducted in Kotabaru District with 32 respondents at random. The data were analyzed with qualitative and quantitative method. Results showed that the profit of the shrimp farming on each planting season was IDR11.031.970 million / ha / season, with a payback period of 7.24. Production risk analysis showed that the coefficient of variance in production was 0.444 with a lower limit of $32,225 \mathrm{~kg}$. The revenue risk analysis showed coefficient of variance of 0.427 with a lower limit of 2,868.491 / ha / season. These results suggest that shrimp farmers do not suffer from production risk due to small production risks and high prices of black tiger shrimps.
\end{abstract}

Keywords: tiger shrimp cultivation; production risks; the risks of farming income; revenue

\section{PENDAHULUAN}

Sumber daya perikanan tangkap dan budi daya merupakan sumber daya alam pesisir yang dapat dikelola dan dikembangkan, pemanfaatan lahan tambak, khususnya budi daya air payau diharapkan dapat menopang target produksi nasional dengan semakin menurunnya produksi perikanan (Alikodra, 2005). Munculnya beberapa penyakit yang mengakibatkan semua jenis udang yang dibudi dayakan tidak dapat tumbuh dengan normal, menyebabkan ribuan hektar tambak udang yang tersebar di 14 kecamatan di Kabupaten Kotabaru, Kalsel dibiarkan terlantar oleh pemiliknya dan beralih fungsi menjadi semak belukar dan rawa-rawa. Kotabaru pernah menjadi primadona usaha udang windu, namun beberapa petambak mengalami kerugian dan meninggalkan tambaknya untuk berusaha perkebunan kelapa sawit. Pada tahun 2006 semua tambak di Kotabaru 
ditata kembali dan dilakukan pembenahan saluran oleh pemerintah setempat, penerapan sistem cara bertambak juga diterapkan agar usaha yang dilakukan dapat berhasil (Anonim, 2008).

Untuk memperoleh udang windu, pedagang pengumpul besar dari dalam negeri berhubungan langsung dengan petambak untuk membeli udang windu, namun banyaknya kendala dalam memperoleh udang windu secara maksimal karena adanya penurunanjumlah produksi disebabkan oleh gagal panen dan akibat faktor alam, hal tersebut dapat diketahui dari hasil penelitian yang dilakukan oleh Nasi, Prayitno \& Sarjito (2007). menyatakan bahwa udang yang stress karena faktor lingkungan yang tidak terkendali dapat membuat sistem imun udang menurun dan dapat menyebabkan udang mudah terinfeksi penyakit. Kualitas produk rendah telah mengakibatkan produk tersebut tidak dapat dijual atau harganya menjadi murah, sehingga berpengaruh kepada pendapatan petani tambak udang.

Penelitian tentang kelayakan usaha dengan menganalisis layak atau tidak suatu usaha untuk pencapaian keuntungan yang maksimal dengan waktu yang tidak ditentukan, merupakan tujuan dalam melakukan penelitian kelayakan usaha (Umar, 2005). (Kasmir \& Jakfar, 2007) mengatakan bahwa ada empat tujuan mengapa perlu adanya studi kelayakan usaha sebelum usaha dilakukan yaitu: 1. Menghindari Resiko Kerugian 2. Memudahkan Perencanaan 3. Mempermudah Pelaksanaan Pekerjaan 4. Memudahkan Pengawasan. Dari hal tersebut sangat jelas mengapa suatu usaha perlu dilakukan analisis resiko, karena, setiap usaha tidak akan terlepas dari kemungkinan resiko yang dapat menimbulkan kerugian besar bagi para pelaku usaha. Ada beberapa resiko yang paling mengancam dalam usaha tambak udang yang disebabkan oleh faktor alam, seperti iklim, cuaca, banjir dan serangan penyakit. Fluktuasi harga juga menjadi resiko dalam usaha tambak udang. Tingkat resiko yang dihadapi oleh usaha tambak udang ini dapat dianalisis dengan menggunakan analisis resiko, maka akan diketahui tingkat resiko yang dihadapi. Resiko yang diukur adalah resiko produksi, dan resiko pendapatan.

Budi daya tambak Kalimantan selatan memiliki potensi tambak dengan luas lahan mencapai 84.998 ha dan telah dimanfaatkan sebesar 16.457,1 ha. Kegiatan budi daya tambak menghasilkan komoditi seperti udang, bandeng dan kakap putih. Untuk komoditi udang, diusahakan untuk menghasilkan udang dari jenis udang windu.

Penelitian mengenai usaha budi daya tambak sering dilakukan namun penelitian dalam hal menganalisis resiko pada petambak penting dilakukan karena untuk melihat kondisi nyata petambak udang windu di Kabupaten Kotabaru dan untuk mendukung penelitian lainnya, dalam hal para petambak dapat mengambil keputusan yang tepat dalam menjalankan usaha dibidang budi daya udang windu sehingga dapat meminimalkan resiko yang akan terjadi. Resiko menunjukkan peluang terhadap suatu kejadian yang dapat diketahui oleh pelaku usaha sebagai pembuat keputusan dalam usaha (Knight, 1921). Peluang kejadian ini dapat ditentukan berdasarkan data historis atau pengalaman selama mengelola kegiatan usaha. Adanya risiko dalam kegiatan usaha pada umumnya akan menimbulkan dampak negatif terhadap pelaku usaha. Seperti yang dikemukakan oleh Harwood, Heifner, Coble, Perry \& Somwaru (1999) bahwa risiko menunjukkan kemungkinan kejadian yang menimbulkan kerugian bagi pelaku usaha yang mengalaminya. Selain itu dari hasil penelitian ini digarapkan dapat memberikan masukan atau saran. Penelitian ini bertujuan untuk mengetahui resiko produksi, menganalisis pendapatan usaha tambak budi daya udang windu dan untuk mengetahui resiko pendapatan usaha budi daya tambak udang di Kabupaten Kotabaru, Provinsi Kalimantan Selatan.

\section{METODOLOGI}

\section{Lokasi Penelitian}

Penelitian ini dilakukan di Kabupaten Kotabaru, Provinsi Kalimantan Selatan (Gambar 1). Lokasi penelitian ini ditetapkan dengan pertimbangan lokasi tersebut merupakan penghasil udang windu dengan produktivitas terbesar di Kabupaten Kotabaru.

\section{Jenis dan Metode Pengumpulan Data}

Data yang digunakan dalam penelitian yaitu data primer dan data sekunder. Data primer merupakan data yang diperoleh melalui wawancara langsung dengan petani tambak udang yang diwakili oleh 32 responden pembudi daya udang windu dan dianggap ahli dibidangnya sehingga data yang didapat mendapatkan kesahihan. Keterwakilan Kotabaru dengan jumlah responden tersebut, dengan luas lahan sebesar 4 hektar yang digunakan dalam perhitungan merupakan data yang 


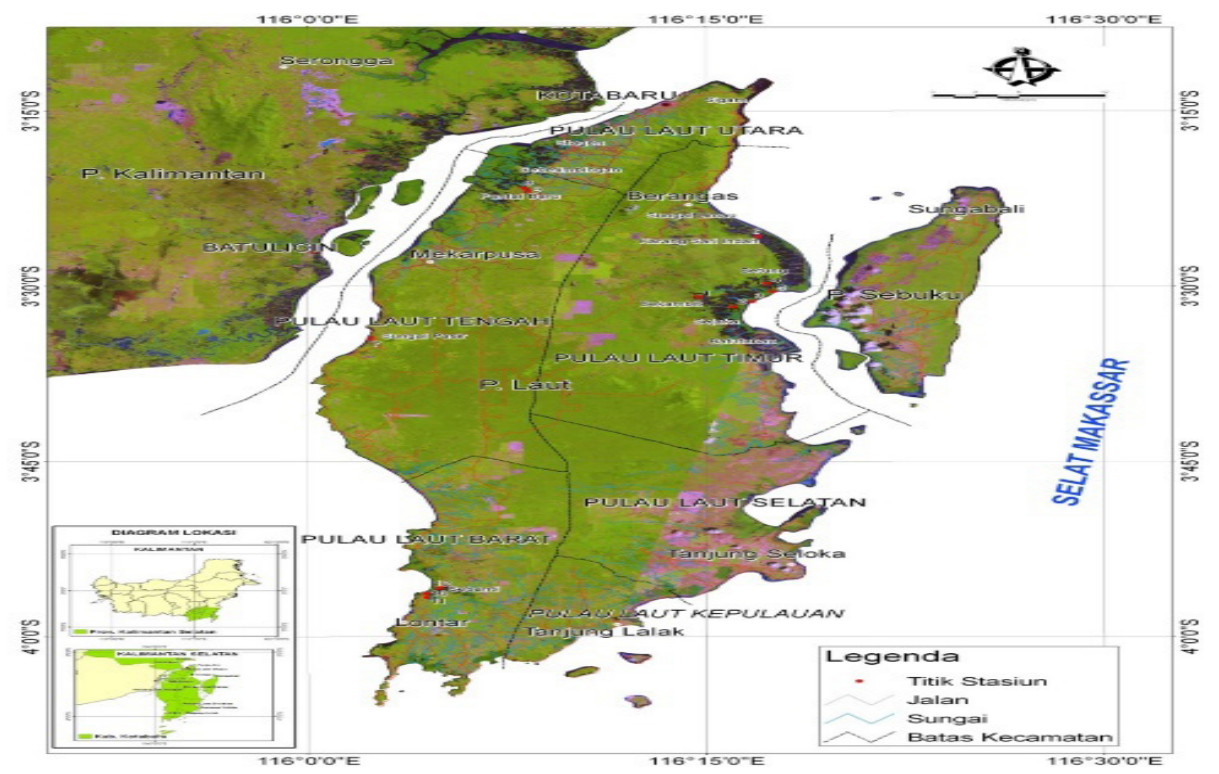

Gambar 1. Peta Lokasi Titik Sampling Penelitian. Figure 1. Map of Sampling Location.

dianggap mewakili persoalan yang sama, sehingga hasilnya dapat menjelaskan hal yang terjadi pada budi daya tambak udang windu di Kabupaten Kotabaru. Data sekunder yang digunakan diperoleh dari literature, baik dari buku, jurnal, maupun hasil penelitian terdahulu yang digunakan sebagai data pelengkap atau penunjang dalam penelitian. Metode pemilihan sampel dalam penelitian ini dilakukan dengan menggunakan metode sampling acak sederhana (Simple Random Sampling).

\section{Metode Analisis}

Analisis data yang digunakan pada penelitian ini terdiri dari analisis kualitatif dengan pendekatan deskriptif dan analisis kuantitatif yaitu dengan analisis resiko untuk menghitung expected value, ragam (variation), simpangan baku (standar deviation), koefisien variasi (standard variation), nilai batas bawah, produksi dan pendapatan. Beberapa penelitian menggunakan metode ini yaitu oleh Ihsanudin (2010) dengan melakukan penelitian untuk mengetahui resiko usahatani tembakau di Kabupaten Magelang. Lamusa (2010) menganalisis resiko usahatani padi sawah rumah tangga di daerah Impenso Provinsi Sulawesi Tengah; sedangkan Imelda (2012) meneliti usaha pada penangkapan kepiting bakau di Kecamatan Sungai Kunyit Kabupaten Pontianak, untuk mengetahui resiko pada usaha tersebut. Arifin (2013) melakukan penelitian di Kabupaten Pinrang tentang resiko produksi dan pendapatan kepemilikan lahan daerah sentra produksi padi. Heriani et al. (2013) melakukan penelitian tentang analisis keuntungan dan resiko usahatani tomat di Kecamatan Sumberejo Kabupaten Tanggamus; sedangkan Saragih et al. (2015) menganalisis resiko produksi dan pendapatan budi daya tambak udang rakyat di Kelurahan Labuhan Deli, Kecamatan Medan Marelan, Kota Medan.

Pengukuran nilai penyimpangan yang terjadi dapat digunakan dalam penilaian resiko. Kadarsan (1995) menjelaskan bahwa dalam menganalisis resiko usaha dilakukan dengan menggunakan langkah-langkah perhitungan hasil yang diharapkan. Ukuran ragam (varian) dan simpangan baku (standar deviasi) digunakan untuk mengukur resiko secara sistematik. Koefisien resiko merupakan perbandingan antara resiko yang harus ditanggung petambak dengan keuntungan yang akan diperoleh sebagai hasil dari sejumlah modal yang diinvestasikan dalam proses produksi. Hal ini menunjukkan semakin besar nilai koefisien resiko, maka semakin besar yang akan ditanggung petani tambak udang. Dalam hal ini, perhitungan dilakukan untuk kegiatan usaha budi daya udang windu selama satu tahun, yang dipanen sebanyak tiga kali dalam setahun.

Metode analisis yang digunakan untuk mendapatkan nilai analisis pendapatan, resiko pendapatan dan resiko produksi adalah sebagai berikut. 
(a) Analisis Tingkat Pendapatan budi daya mengacu pada Shinta (2011): pendapatan usaha adalah selisih penerimaan dengan semua biaya produksi, dirumuskan sebagai berikut:

$$
\pi=\mathrm{TR}-\mathrm{TC}=(\mathrm{Y} . \mathrm{Py})-(\mathrm{FC}+\mathrm{VC})
$$

Keterangan/Remaks :

$\pi \quad$ = Pendapatan petambak dalam satu kali musim)

(Rp)/ Farmer income in one season (IDR)

$\mathrm{TR}=$ Total penerimaan $(\mathrm{Rp}) /$ Total revenue $(I D R)$

$\mathrm{TC}=$ Total biaya (Rp)/ Total cost (IDR)

$\mathrm{Y}=$ Jumlah produksi $(\mathrm{kg}) /$ Amount production $(\mathrm{kg})$

$\mathrm{Py}=$ Harga satuan produk (Rp) /Price unit product (IDR)

$\mathrm{FC}=$ Biaya tetap (Rp)/Fixed cost (IDR)

$\mathrm{VC}=$ Biaya tidak tetap $(\mathrm{Rp}) /$ Variable cost (IDR)

Untuk mengetahui apakah usaha menguntungkan atau tidak maka digunakan analisis R/C rasio (Return Cost Ratio). R/C rasio merupakan perbandingan (nisbah) antara penerimaan total dan biaya total (Shinta, 2011) yang dituliskan sebagai berikut :

$$
\mathrm{R} / \mathrm{C}=\frac{\mathrm{TR}}{\mathrm{TC}}
$$

Keterangan/Remaks :

$\mathrm{R} / \mathrm{C}=$ Nisbah antara penerimaan dan biaya/Ratio Revenue and Cost

$\mathrm{TR}=$ Penerimaan total $\mathrm{Rp}) /$ Total Revenue (IDR)

$\mathrm{TC}=$ Biaya total (Rp)/ Total Cost (IDR)

Kriteria pada pengukuran tersebut adalah sebagai berikut :

1) Jika $R / C>1$, maka usahatani yang dilakukan menguntungkan, karena penerimaan lebih besar dari biaya total,

2) Jika $R / C<1$, maka usahatani yang dilakukan tidak menguntungkan, karena penerimaan lebih kecil dari biaya total,

3) Jika $\mathrm{R} / \mathrm{C}=1$, maka usahatani yang dilakukan tidak rugi maupun tidak untung, karena penerimaan sama besar dengan biaya total atau impas.

(b) Analisis Risiko budi daya udang. Semakin tinggi risiko yang harus dihadapi, semakin tinggi hasil yang diharapkan tercapai. Risiko terdiri dari risiko produksi, risiko harga dan risiko pendapatan. Risiko usaha dapat dihitung dengan melihat data produksi dan harga pada musim budi daya sebelumnya. Tingkat produksi dan harga berpengaruh terhadap tingkat pendapatan yang secara signifikan dapat mengindikasikan adanya risiko pada usaha budi daya udang yang dilakukan. Ukuran untuk hasil yang diharapkan adalah hasil rata-rata atau mean, rumusnya yaitu:

$$
\mathrm{E}=\frac{\sum_{i=1}^{n} E i}{n}
$$

Keterangan/Remaks :

$\mathrm{E}=$ Rata-rata nilai yang diharapkan/ Average value expected

$\mathrm{Ei}=$ Pendapatan yang diperoleh musim ke- $\mathrm{i} /$ Revenue earned in season - $i$

$\mathrm{n}$ = Jumlah pengamatan risiko secara statistik dapat diukur dengan ukuran ragam atau simpangan baku/The number of observations of risk can be statistically measured by standard size or deviation

Kedua cara ini menjelaskan risiko dalam arti kemungkinan penyimpangan pengamatan sebenarnya di sekitar nilai rata-rata yang diharapkan. Ukuran rumus ragam adalah sebagai berikut :

$$
\mathrm{V}^{2}=\frac{\sum_{i=1}^{n}(E i-E) 2}{(n-1)}
$$

Sedangkan simpangan baku merupakan akar dari ragam, atau yang secara matematis dirumuskan sebagai berikut :

$$
\mathrm{V}=\sqrt{V}_{2}
$$

Keterangan/Remaks :

$\mathrm{V}^{2}=$ Ragam/Variance

$\mathrm{V}$ = Simpangan baku/Standard deviation

$\mathrm{E}$ = Rata-rata nilai yang diharapkan/Average value expected

$\mathrm{Ei}$ = Pendapatan yang diperoleh pada musim ke-i/ Revenue earned in season - i)

$\mathrm{n}$ = Jumlah pengamatan/Amount observation

Untuk melihat tingkat risiko yang paling rendah dalam memberikan suatu hasil dapat dipakai ukuran keuntungan koefisien variasi dengan rumus sebagai berikut :

$$
\mathrm{CV}=\frac{V}{E}
$$

Keterangan/Remaks :

$\mathrm{CV}=$ Koefisien variasi/Coefficient of Variation

$\mathrm{V}=$ Simpangan baku/Standard deviation

$\mathrm{E}=$ Rata-rata nilai yang diharapkan/Average value expected 
Batas bawah $(L)$ menunjukkan nilai terendah produksi, harga dan pendapatan yang mungkin diterima oleh petani tambak udang.

Rumus perhitungan batas bawah $(\mathrm{L})$ adalah :

$$
\mathrm{L}=\mathrm{E}-2 \mathrm{~V}
$$

Keterangan/Remaks:

$\mathrm{L}=$ Nilai batas bawah/Low value

$\mathrm{V}=$ Simpangan baku/Standard deviation

$\mathrm{E}=$ Rata-rata nilai yang diharapkan/Average value expected

Nilai CV menunjukan besarnya variasi dari setiap rata-rata nilai harapan yang diperoleh. Angka variasi yang cukup tinggi menunjukan bahwa risiko yang dialami tinggi dan angka variasi yang rendah menunjukan bahwa risiko yang dialami rendah. $L$ merupakan nilai batas bawah dari suatu selang kepercayaan. Apabila usaha yang dilakukan mengalami kerugian maka kerugian yang harus ditanggung adalah sebesar nilai $\mathrm{L}$.

Hubungan antara batas bawah hasil tertinggi (L) dengan koefisien variasi (CV) yakni: Jika CV $>0,5$ maka $L<0$ artinya ada peluang kerugian yang akan diderita oleh suatu usaha; Jika $\mathrm{CV}<0,5$ maka $\mathrm{L}>0$ artinya suatu usaha akan selalu terhindar dari kerugian. Hasan (2002) menyatakan bahwa untuk dapat menggunakan metode descript maka seseorang peneliti harus memiliki sifat represif, selalu mencari bukan menguji, memiliki kekuatan integrative untuk memadukan berbagai macam informasi yang diterimanya menjadi satu kesatuan penafsiran.

\section{HASIL DAN PEMBAHASAN}

\section{Gambaran Umum Lokasi Penelitian}

Kabupaten Kotabaru memiliki lahan terluas dibandingkan dengan kabupaten-kabupaten lain di Provinsi Kalimantan Selatan, yaitu 9.422,46 $\mathrm{km}^{2}$ atau $25,21 \%$ dari luas wilayah Provinsi Kalimantan Selatan. Sebagian wilayahnya terdiri dari beberapa pulau dan sebagian lagi wilayah daratan yang terletak di Pulau Kalimantan. Pulaupulau besar dan kecil yang dimiliki Kabupaten Kotabaru berjumlah 111 buah, di antaranya, yaitu: Pulau Laut, Pulau Sebuku, Pulau Kerayaan, dan lain-lain. Secara administratif, Kabupaten Kotabaru tersebut dibagi menjadi 20 kecamatan dan 197 desa serta 4 kelurahan. Kabupaten Kotabaru memiliki potensi lahan budi daya tambak udang dan bandeng sekitar 52.900 ha yang tersebar di 6 (enam) kecamatan, namun sampai saat ini belum dimanfaatkan secara optimal, hal ini ditandai dengan produksi yang baru mencapai 22.450 ton/ tahun. Oleh karena itu masih terbuka peluang untuk mengembangkan usaha budi daya tambak melalui pemanfaatan dan penerapan teknologi budi daya tambak yang telah berkembang sesuai dengan kondisi lahan yang ada. Tambak yang ada (eksisting) di Kabupaten Kotabaru berada di sebagian daratan Pulau Kalimantan dan sebagian di Pulau Laut yang umumnya adalah tambak ekstensif (tradisional). Untuk menyesuaikan dengan program Dinas Kelautan dan Perikanan Kabupaten Kotabaru, survei pengambilan data primer dan sekunder difokuskan pada wilayah tambak yang ada di Pulau Laut, dan dianggap dapat mewakili tambak yang ada di Kabupaten Kotabaru, penentuan jumlah responden berdasarkan hasil pengamatan di lapangan dan dianggap dapat mewakili dalam pengambilan data serta memiliki keahlian dalam mengelola tambak, sehingga data yang diperoleh sangat sahih. Komoditas yang diutamakan untuk budi daya air payau di Kabupaten tersebut yaitu udang windu dan ikan bandeng dan dilakukan secara polikultur, namun sebagian juga melakukan budi daya secara terpisah antara kedua komoditas tersebut (Razi, 2012).

\section{Karakteristik petambak}

Karakteristik petambak sangat menentukan keberhasilan suatu usaha yang mereka lakukan. Menurut Ndraha (1999) sumber daya manusia berkualitas tinggi adalah sumber daya manusia yang mampu menciptakan bukan saja nilai komparatif tetapi juga nilai kompetitif-generatifinovatif dengan menggunakan energi tertinggi seperti intelligence, creativity, dan imagination: tidak lagi semata-mata menggunakan energi kasar seperti bahan mentah, lahan, air, tenaga otot, dan sebagainya. Dari penjelasan tersebut maka dapat dipahami bahwa umur dan tingkat pendidikan sangat menentukan suatu keberhasilan usaha. Umur petambak udang windu di lokasi penelitian berkisar antara 29 - 57 tahun, dengan rata-rata 41 tahun. Usia produktif berkisar antara 15 - 64 tahun dan usia yang tidak produktif antara 0 - 14 tahun dan 65 tahun keatas (Mubyarto, 1989). Usia produktif dalam hal ini menunjukkan bahwa mereka lebih memberikan hasil maksimal dibandingkan dengan usia yang tidak produktif, hal ini disebabkan karena pada usia produktif, umumnya seseorang memiliki kemampuan yang 
lebih baik dalam berfikir dan bertindak untuk melakukan kegiatan, dengan usia tersebut berpengaruh terhadap banyak atau sedikitnya pengalaman petani tambak udang dalam usaha budi daya. Lamanya pengalaman dalam mengelola tambak akan dapat menjadi pelajaran dalam hal pengelolaan dan memperbaiki kekurangan dalam melakukan usaha budi daya untuk meningkatkan produksi.

Tingkat pendidikan dianggap penting dalam meningkatkan suatu usaha, dengan tingkat pendidikan lebih baik sangat berhubungan dengan pengembangan sumber daya manusia karena biasanya berkaitan dengan peningkatan kemampuan intelektual untuk melaksanakan pekerjaan yang lebih baik. Dengan tingkat pendidikan dapatmempengaruhi pola berpikir dalam mengelola usahanya. Semakin tinggi pendidikan seseorang, maka akan semakin luas wawasannya dan semakin membuka diri terhadap kemajuan teknologi, tingkat pendidikan formal petambak udang di Kabupaten Kotabaru yang berpendidikan SD $65.62 \%$, pendidikan SLTP sebesar $21.87 \%$ dan pendidikan SLTA sebesar $12.5 \%$. Tingginya tingkat pendidikan ini akan mempengaruhi pola pikir petambak dalam mengadopsi informasi. Petani tambak udang diharapkan dapat dengan mudah menyerap informasi tentang usaha budi daya tambak udang baik lewat radio, televisi, surat kabar ataupun sumber informasi lainnya.

Hasil penelitian yang diperoleh berdasarkan pengalaman usaha tambak yang paling banyak berada pada kategori 1 sampai 39 tahun dengan rata-rata sebesar $16.28 \%$. Pengalaman bertambak ini akan membantu petambak dalam mengolah tambak udangnya, karena pengalaman dalam berusaha budi daya tambak udang merupakan salah satu faktor yang mendukung petambak dalam menjalankan usahanya dengan lebih baik, serta lebih bijak dalam menyikapi setiap perubahan yang terjadi, baik yang mendatangkan kerugian maupun keuntungan dari hasil kegiatan tersebut dan dapat membantu petambak dalam mengambil keputusan untuk usaha periode musim tebar berikutnya.

Rata-rata luas lahan yang digarap oleh petambak Kabupaten Kotabaru berada pada kategori 1 ha sampai $16 \mathrm{Ha}$, namun dalam penelitian ini digunakan luas 4 ha sebagai perwakilan dalam perhitungan. Besar atau kecilnya luas lahan dalam budi daya berdsarkan kemampuan modal untuk membeli atau menyewa lahan budi daya tambak udang. Hal tersebut juga berhubungan dengan banyaknya tenaga kerja yang digunakan diluar keluarga. Semakin banyak menggunakan tenaga kerja, maka semakin besar pula biaya yang harus dikeluarkan. Jadi, luas lahan akan mempengaruhi besar atau kecilnya biaya produksi yang dikeluarkan oleh petambak udang.

\section{Biaya Usaha Budi daya Tambak Udang}

Usaha budi daya udang windu merupakan salah satu jenis usaha di bidang perikanan dan kelautan yang dalam pelaksanaannya untuk menghasilkan produksi, pendapatan dan keuntungan diperlukan biaya-biaya yang meliputi biaya tetap (Fixed Cost) maupun biaya tidak tetap (Variable Cost). Keuntungan/profit dalam melakukan suatu usaha, adalah tujuan utama bagi pelaku usaha, agar usaha yang dijalankan terus dapat berkembang dan maju. Oleh karena itu, bagi pelaku usaha penerapan prinsip ekonomi dalam menjalankan usahanya harus dijalankan. Pengertian prinsip ekonomi dalam menjalankan usaha untuk mendapatkan keuntungan sebesarbesarnya dengan biaya yang dikeluarkan sekecilkecilnya. Total biaya investasi yang dikeluarkan untuk usaha budi daya udang dengan luasan 4 ha pertahun adalah sebesar Rp.79.959.000,(Tabel 1). Biaya-biaya yang dikeluarkan antara lain biaya tetap, biaya operasional (Tabel 2). Harga jual untuk udang windu tergantung ukuran udang, untuk size 40 harga jualnya Rp. $72.000 / \mathrm{Kg}$. Dari seluruh biaya tidak tetap, biaya yang paling besar dikeluarkan adalah biaya untuk pakan disusul oleh benih. Tingginya harga pakan sering menjadi kendala utama bagi para pembudi daya sehingga tak jarang pembudi daya memberikan pakan alternative lain yang harganya lebih terjangkau untuk menekan pengeluaran biaya pakan yang cukup besar.

Penerimaan/pendapatan adalah hasil kali jumlah produksi dikalikan dengan harga ikan/udang. Adapun total penerimaan/pendapatan usaha budi daya tambak sebesar Rp.26.642.763/ha/musim tanam (Tabel 3). Keuntungan adalah selisih dari total penerimaan dikurangi total seluruh biaya yang dikeluarkan. Keuntungan yang diperoleh sebesar Rp.11.031.970,-. R/C rasio usaha budi daya adalah sebesar 2.94 artinya kondisi ini menunjukkan usaha budi daya udang windu di Kabupaten Kotabaru layak untuk diusahakan.

\section{Analisis Resiko Produksi dan Pendapatan}

Pengambilan keputusan sebelum memulai 
Tabel 1. Kebutuhan Investasi dan Penyusutan Usaha Budi Daya Tambak di Kabupaten Kotabaru, 2016. Table 1. Investment Needs and Depreciation of Pond Cultivation Business in Kotabaru District, 2016.

\begin{tabular}{|c|c|c|c|c|c|c|}
\hline No & Uraian/Description & Jumlah/Amount & $\begin{array}{l}\text { Investasi (Rp)/ } \\
\text { Investment } \\
\text { (IDR) }\end{array}$ & $\begin{array}{l}\text { U. E } \\
\text { (th) } l \\
\text { (year) }\end{array}$ & $\begin{array}{c}\text { Penyusutan } \\
\text { Tahun (Rp) } \\
\text { (Depreciation)l } \\
\text { year (IDR) } \\
\end{array}$ & $\begin{array}{l}\text { Penyusutan } \\
\text { Musim (Rp) } \\
\text { Depreciation } \\
\text { Season (IDR) }\end{array}$ \\
\hline \multirow[t]{6}{*}{1} & $\begin{array}{l}\text { Investasi Lahan \& dan } \\
\text { Bangunan/Land and } \\
\text { Building Investment }\end{array}$ & & & & & \\
\hline & $\begin{array}{l}\text { 1. Konstruksi tambak } \\
\text { pembesaran/Construction of } \\
\text { enlargement ponds }\end{array}$ & 4 ha $(H a)$ & $40,000,000$ & 5 & $8,000,000$ & $4,500,000$ \\
\hline & $\begin{array}{l}\text { 2. Sewa tambak pembesaran/ } \\
\text { Rent ponds enlargement }\end{array}$ & 4 ha $(H a)$ & $14,000,000$ & 3 & $4,666,667$ & $2,500,000$ \\
\hline & $\begin{array}{l}\text { 3. Kontruksi saluran/Canal } \\
\text { construction }\end{array}$ & 1 unit (Unit) & $1,000,000$ & 4 & 250,000 & 500,000 \\
\hline & 4. Pintu Air/luice & 1 unit (Unit) & $3,000,000$ & 5 & 600,000 & 100,000 \\
\hline & 5. Rumah jaga/Guard house & 1 buah (Piece) & $2,000,000$ & 5 & 400,000 & 200,000 \\
\hline \multirow[t]{8}{*}{2} & Sub.lahan \& bangunan & & $60,000,000$ & & $13,916,667$ & $7,800,000$ \\
\hline & Peralatan/Material & & & & & \\
\hline & $\begin{array}{l}\text { 1. Traktor/Tractor } \\
\text { 2. Mesin pompa/Pump } \\
\text { Machine }\end{array}$ & $\begin{array}{l}1 \text { unit (Unit) } \\
1 \text { unit (Unit) }\end{array}$ & $\begin{array}{l}7,000,000 \\
2,000,000\end{array}$ & $\begin{array}{l}5 \\
5\end{array}$ & $\begin{array}{r}1,400,000 \\
400,000\end{array}$ & $\begin{array}{l}700,000 \\
200,000\end{array}$ \\
\hline & 3. Perahu sampan/Boat & 1 buah (Piece) & $3,000,000$ & 3 & $1,000,000$ & 500,000 \\
\hline & $\begin{array}{l}\text { 4. Kincir air/Water wheel } \\
\text { 6. Jaring/Nets } \\
\text { 7. Jala/Net }\end{array}$ & $\begin{array}{c}1 \text { unit (Unit) } \\
1 \text { buah (Piece) }\end{array}$ & $\begin{array}{l}4,000,000 \\
2,000,000\end{array}$ & $\begin{array}{l}3 \\
3\end{array}$ & $\begin{array}{r}1,333,333 \\
666,667\end{array}$ & $\begin{array}{l}666,667 \\
333,333\end{array}$ \\
\hline & $\begin{array}{l}\text { 8. Pipa pralon/Pralon pipes } \\
\text { 9. Baling baling/Propeller } \\
\text { 10. Porok/Porok }\end{array}$ & $\begin{array}{l}2 \text { buah }(\text { Piece) } \\
1 \text { buah (Piece) } \\
2 \text { buah (Piece) }\end{array}$ & $\begin{array}{l}150,000 \\
300,000 \\
800,000\end{array}$ & $\begin{array}{l}2 \\
2 \\
4\end{array}$ & $\begin{array}{r}75,000 \\
150,000 \\
200,000\end{array}$ & $\begin{array}{r}37,500 \\
75000 \\
100,000\end{array}$ \\
\hline & $\begin{array}{l}\text { 11. Bila-bila/Bila-bila } \\
\text { 12. Box/Box }\end{array}$ & 1 buah (Piece) & 130,000 & 1 & 130,000 & 65,000 \\
\hline & & $\begin{array}{l}1 \text { buah (Piece) } \\
3 \text { buah (Piece) } \\
4 \text { buah (Piece) }\end{array}$ & $\begin{array}{r}250,000 \\
249,000 \\
80,000\end{array}$ & $\begin{array}{l}1 \\
1 \\
2\end{array}$ & $\begin{array}{r}250,000 \\
249,000 \\
40,000\end{array}$ & $\begin{array}{r}125,000 \\
124,500 \\
20,000\end{array}$ \\
\hline \multirow[t]{2}{*}{3} & $\begin{array}{l}\text { Sub. Inv.peralatan/ } \\
\text { Sub Equipment Investments }\end{array}$ & & $19,959,000$ & & $5,894,000$ & $2,947,000$ \\
\hline & $\begin{array}{l}\text { Total investasi/ } \\
\text { Total Investment }\end{array}$ & & $79,959,000$ & & $19,810,667$ & $9,905,533$ \\
\hline
\end{tabular}

Tabel 2. Biaya Operasional Usaha Budi Daya Udang Windu di tambak, di Wilayah Kabupaten Kotabaru, 2016. Table 2. Operational Cost of Black Tiger Shrimp Farming, in Kotabaru District, 2016.

\begin{tabular}{|c|c|c|c|c|}
\hline No & Uraian/Description & Volume/Volume & $\begin{array}{c}\text { Harga satuan (Rp)/ } \\
\text { Unit Price (IDR) }\end{array}$ & $\begin{array}{c}\text { Nilai Rp/ } \\
\text { Value (IDR) }\end{array}$ \\
\hline \multirow[t]{9}{*}{$\mathrm{I}$} & Biaya Operasional (Operational costs) & & & \\
\hline & - Benih (Seed) & 14.456 & 50 & 722,800 \\
\hline & - Pakan (Feed) (Kg) & 500 & 3,500 & $1,750,000$ \\
\hline & $\begin{array}{l}\text { - Pupuk (Fertilizer) } \\
\text { - Urea (Urea) (kg) }\end{array}$ & 107.53 & 3,000 & 322,590 \\
\hline & - SP36 (SP36) (kg) & 130.47 & 4,000 & 521,880 \\
\hline & Saponin (Saponin) (kg) & 25.97 & 8,000 & 207,760 \\
\hline & Solar (Solar) (L) & 320 & 8,000 & 256,000 \\
\hline & Tenaga kerja (Labor) (orang (Human) & 5 & 100,000 & 500,000 \\
\hline & Jumlah (Amount) I & & & $4,281,030$ \\
\hline \multirow[t]{6}{*}{ II } & Biaya Tetap (Fixed cost) & & & \\
\hline & -Penyusutan (Shrinkage) & & & $2,947,000$ \\
\hline & -Perawatan alat (Maintenance tools) & & & 50,000 \\
\hline & -Pajak lahan (Land Tax) & & & 50,000 \\
\hline & Jumlah (Amount) II & & & $3,047,000$ \\
\hline & $\begin{array}{l}\text { Total biaya operasional (Total } \\
\text { operational cost) }\end{array}$ & & & $7,328,030$ \\
\hline
\end{tabular}


Tabel 3. Analisis Finansial Usaha Budi Daya Udang dan Bandeng Permusim Tanam di Wilayah Kabupaten Kotabaru, 2016.

Table 3. Financial Analysis of Shrimp and Milkfish Farming of Each Season in Kotabaru District, 2016.

\begin{tabular}{llr}
\hline No & \multicolumn{1}{c}{ Uraian/Description } & Nilai/Value \\
\hline & Penerimaan (Receipt) : & \\
1 & Produksi/ pendapatan (Production/ income) & $26,642,763$ \\
2 & PPh (Income tax) (15\%) & $3,240,000$ \\
3 & Penerimaan setelah PPh (Receipts after income tax) & $18,360,000$ \\
4 & Keuntungan (Profit) & $11,031,970$ \\
5 & R/C ratio (R/C ratio) & 2.94 \\
6 & Pay back periode (Pay Back Period) & 7.24 \\
\hline
\end{tabular}

suatu usaha sangat penting bagi petambak dengan melakukan analisis resiko dalam memulaiusahanya. Hasil yang diperoleh oleh petambak dalam periode tertentu merupakan dasar dalam pendekatan dalam melakukan analisis. Data produksi dan pendapatan dari hasil usaha merupakan data yang digunakan untuk menganalisis resiko petambak udang. Produksi adalah proses kombinasi dan koordinasi material-material dan kekuatankekuatan (input, faktor, sumber daya atau jasa-jasa produksi) dalam pembuatan suatu barang atau jasa (output atau produk), sedangkan fungsi dari produksi yaitu memberikan output maksimum dalam pengertian fisik dari tiap-tiap tingkat input (Beattie \& Taylor, 1996). Dalam proses produksi terkandung hubungan antara tingkat penggunaan faktor-faktor produksi dengan produk atau hasil yang akan diperoleh. Hal ini disebut dengan hubungan antara input dan output. Di samping itu, dalam menghasilkan suatu produk dapat pula dipengaruhi oleh produk yang lain, bahan untuk menghasilkan produk tertentu dapat digunakan input yang satu maupun input yang lain, adanya biaya yang tersedia berhubungan langsung dengan peran petambak sebagai manajer dalam mengelola usahanya. Seberapa besar tingkat penggunaan biaya produksi maka akan menurunkan pendapatan usahanya (Suratiyah, 2009). Dari hal tersebut ada beberapa penyebab dari menurunnya hasil produksi yaitu adanya serangan hama dan penyakit yang terjadi secara mendadak dan meluas, hal ini merupakan resiko dalam produksi dan dapat menurunkan hasil hingga $65 \%$ yang menyebabkan gagal panen (Cahyono, 2008), adanya masalah yang ditemukan dalam usaha memerlukan kecakapan petambak dalam mengatasinya. Selain hal tersebut untuk memperoleh kesuksesan suatu budi daya beberapa hal yang harus diperhatikan yaitu (1) Untuk pengendalian siklus reproduksi suatu organisme budi daya secara lengkap hal yang perlu diperhatikan; mengetahui genetik induk dengan baik, dan penentuan (diagnosa) penyakit serta pencegahan terjadinya penyakit harus dilakukan secara cermat; (2) Penyediaan air yang cukup dengan kualitas baik dan pemahaman yang benar berdasarkan fisiologi lingkungan serta kondisi nutrisi, dan; (3) Aplikasi teknik manajemen inovatif (Chen, 2000)

Dari hasil perhitungan, nilai $L$ yang diperoleh yaitu sebesar $32.225 \mathrm{~kg} / \mathrm{ha}$. Angka-angka tersebut menunjukkan batas minimal produksi yang harus dihasilkan petambak dimasa mendatang. Apa bila

Tabel 4. Analisis Resiko Produksi dan Pendapatan Budi Daya Tambak Udang, di Kabupaten Kotabaru, Provinsi Kalimantan Selatan, 2016

Table 4. Analysis of Production Risk And Income Risk of Shrimp Ponds, in Kotabaru District, South Kalimantan Province, 2016.

\begin{tabular}{lcc}
\hline \multicolumn{1}{c}{ Uraian/Description } & $\begin{array}{c}\text { Produksi Siklus/ } \\
\text { Production Cycle }\end{array}$ & $\begin{array}{c}\text { Pendapatan Siklus/ } \\
\text { Income Cycle }\end{array}$ \\
\hline Rata-Rata/Mean & 291,667 & $19,732,142$ \\
Varian/Varian & 16827.38 & $7,109,568$ \\
Simpangan Baku/Standard deviation & 129,720 & $8,431,825$ \\
Koefisien variasi/Coefficient of variation & 0.444 & 0.427 \\
Batas bawah/Lower Limit & 32,225 & $2,868,491$ \\
\hline
\end{tabular}


dilihat dari kriteria hubungan antara nilai CV dan $L$ yaitu apabila $C V>0.5$ maka $L<0$, maka usaha tersebut akan berpeluang mengalami kerugian, apabila CV $<0,5$ maka $\mathrm{L}>0$ maka usaha tersebut akan terhindar dari kerugian. Karena usaha tersebut memiliki nilai $C V<0.5$ dan nilai $L>0$, ini artinya usaha tambak udang pada setiap periodenya akan terhindar dari resiko produksi.

Resiko pendapatan dapat diukur dari besarnya pendapatan yang diharapkan dari kegiatan budi daya, berdasarkan nilai simpangan baku diperoleh hasil sebesar 8.431.825/ha. Koefisien variasi diperoleh hasil sebanyak 0.427 artinya untuk Rp 1 yang diterima petambak akan menghasilkan resiko sebesar $\mathrm{Rp}$ 0.427. Batas bawah pendapatan (L) yang dihasilkan sebesar 2.868.491. Angka tersebut menunjukkan jumlah pendapatan terendah yang harus diterima oleh petambak udang dimasa yang akan datang. Dilihat dari keriteria hubungan antara nilai $\mathrm{CV}$ dan $\mathrm{L}$, maka usaha tambak udang pada setiap periodenya terhindar dari kerugian atau resiko yang diderita kecil sekali.

\section{KESIMPULAN DAN REKOMENDASI KEBIJAKAN}

\section{Kesimpulan}

Hasil analisis menunjukkan bahwa pendapatan petambak di Kabupaten Kotabaru lebih besar dibandingkan dengan total biaya yang dikeluarkan selama proses budi daya. Hal ini berarti usaha budi daya tambak udang tersebut menguntungkan. Nilai koefisien variasi produksi dan pendapatan yang diperoleh sebesar 0,4 dan nilai batas bawah produksi dan pendapatan yang diperoleh lebih besar dari 1 , namun untuk melihat secara keseluruhan dari nilai $\mathrm{CV}<0,5$ dan nilai $L>0$, yang menunjukkan bahwa petambak udang akan terhindar dari resiko produksi dan usaha tersebut akan terhindar dari kerugian.

\section{Implikasi Kebijakan}

Kebijakan pemerintah setempat dibutuhkan dalam hal pengembangan sumberdaya manusia dan penerapan sistem kelembagaan manajemen mutu untuk penanganan resiko dalam produksi, pelatihan penerapan pengelolaan budi daya tambak secara maksimal dan ramah lingkungan, sangat penting untuk ditingkatkan agar resiko dalam melakukan budi daya dapat dihindari dan memperoleh jumlah produksi sesuai harapan pembudi daya.

\section{UCAPAN TERIMAKASIH}

Ucapan terima kasih kepada tim peneliti dan para teknisi Balai Riset Perikanan Budi Daya Air Payau dan Penyuluhan Perikanan (BRPBAP3) Maros yang turut membantu dalam pelaksanaan penelitian ini.

\section{DAFTAR PUSTAKA}

Alikodra, H, S. (2005). Konsep Pengelolaan Wilayah Pesisir Secara Terpadu dan Berkelanjutan. Makalah disampaikan pada Pelatihan ICZPMAngkatan III/2005 Prov. NTB.

Anonim. (2008). Ribuan Hektare Tambak Udang Kotabaru Ditelantarkan. Retrieved from https:// www.merdeka.com/uang/ribuan-hektare-tambakudang-kota-baru-ditelantarkan.

Arifin. (2013). Resiko Produksi dan Pendapatan Kepemilikan Lahan Daerah Sentra Produksi Padi di Kabupaten Pinrang. Jurnal Vegeta 7 (1): 1-14. Retrieved from https://www.researchgate.net/ publication/324817508.

Beattie, B.R \& C.R. Taylor. (1996). Ekonomi Produksi. Yogyakarta: UGM Press.

Cahyono, B. (2008). Tomat; Usahatani dan Penanganan Pascapanen. Yogyakarta: Kanisius.

Chen, T.T. (2000). Aquaculture Biotechnology and Fish Disease. In: Hardjito, L. (Ed). International Symposium on Marine Biotechnology. Jakarta: Center for Coastal and Marine Resources Studies, IPB.

Harwood, J., Heifner, R., Coble, K., Perry, J., \& Somwaru, A. (1999). Market and Trade Economics Division and Resource Economics Division, Economic Research Service, U.S. Department of Agriculture. Agricultural Economic Report No. 774. Retrieved from https://www.ctahr.hawaii. edu/agrisk/pdfs/gnrIRMA/Managing\%20RiskIn Farming.pdf

Hasan, I. (2002). Pokok - pokok Materi Metodologi Penelitian dan Aplikasinya. Jakarta: Ghalia Indonesia.

Heriani, N., W.A. Zakaria, \& A. Soelaiman. (2013). Analisis Keuntungan dan Resiko Usahatani Tomat di Kecamatan Sumberejo Kabupaten Tanggamus. Jurnal IIA. 1 (2): 169-173. doi: 10.23960/jiia.v1i2.

Ihsanudin. (2010). Resiko Usahatani Tembakau di Kabupaten Magelang. Jurnal Embryo. 7 (1): 21-28.

Imelda. (2012). Analisis Resiko Pada Usaha Penangkapan Kepiting Bakau Di Kecamatan Sungai Kunyit Kabupaten Pontianak. Jurnal Sosial Ekonomi Pertanian. 1 (1): 75-95. 
Kasmir \& Jakfar. (2007). Studi Kelayakan Bisnis. Jakarta: Edisi 2. Kencana.

Kadarsan, H.W. (1995). Keuangan Pertanian dan Pembiayaan Perusahaan Agribisnis. Jakarta: Cetakan Kedua. PT. Gramedia Pustaka Utama.

Knight, F.H. (1921). Risk, Uncertainty and Profit. Boston (US): Houghton Mifflin.

Lamusa A. (2010). Resiko Usahatani Padi Sawah Rumah Tangga di Daerah Impenso Provinsi Sulawesi Tengah. Jurnal Agroland. 17(3):226-232.

Mubyarto. (1989). Pengantar Ekonomi Pertanian. Jakarta: LP3ES.

Nasi, L., Prayitno, \& S.B, Sarjito. (2007). Kajian bakteri penyebab vibriosis pada udang secara biomolekuler. Jurnal Management sumberdaya pantai. 3(1):1-22

Razi, F. (2012). Potensi Perikanan Kabupaten Kotabaru. Retrieved from http://komunitaspenyuluhperikanan.blogspot.com/2012/06/potensi-perikanan-kabupaten-kotabaru.

Saragih, N.S. (2015). Analisis Resiko Produksi Dan Pendapatan Budi daya Tambak Udang Rakyat Di Kelurahan Labuhan Deli, Kecamatan Medan Marelan, Kota Medan. Jurnal Agrisep. 14 (1): $39-52$.

Suratiyah, K. (2009). IImu Usahatani. Jakarta: Penebar Swadaya.

Umar, H. (2005). Studi Kelayakan Bisnis. Jakarta: Gramedia Pustaka Utama. 